\title{
PERENCANAAN DAN PENGENDALIAN PRODUKSI AGREGAT PADA USAHA TEDUNG UD DWI PUTRI DI KLUNGKUNG
}

\author{
I Komang Juliantara ${ }^{1}$ \\ Kastawan Mandala ${ }^{2}$ \\ ${ }^{1,2}$ Fakultas Ekonomi dan Bisnis Universitas Udayana (Unud), Bali, Indonesia \\ email: komangjuliantara96@gmail.com
}

\begin{abstract}
ABSTRAK
Perencanaan dan pengendalian produksi sangat penting dilakukan untuk meminimalisir terjadinya kelebihan persediaan produk jadi pada musim permintaan yang rendah dan sebaliknya terjadi kekurangan produk pada musim permintaan yang tinggi. Tujuan dari penelitian ini adalah mengetahui serta menentukan jumlah produksi dengan biaya yang minimal pada UD Dwi Putri Klungkung. Penelitian ini dilakukan pada produk tedung dengan menggunakan sistem perencanaan produksi agregat adapun data-data yang digunakan dalam penelitian ini yaitu data penjualan selama satu tahun, katasitas produksi, biaya lembur, biaya penyimpanan dan biaya tenaga kerja. Berdasarkan hasil penelitian menunjukkan bahwa jumlah perkiraan produk yang diproduksi selama satu tahun kedepan yaitu sebanyak 31.531 unit, yang didasarkan pada metode exponential smoothing. Metode ini digunakan, karena metode exponential smoothing memberikan hasil yang memiliki standar error yang terkecil dengan nilai MAD sebesar 208.812, nilai MSE sebesar 61843.5 dan nilai MAPE sebesar $7.97 \%$.Strategi perencanaan agregat dengan chase strategy menghasilkan total biaya produksi Rp 242,995,500.00, dimana total biaya tersebut lebih rendah, jika dibandingkan dengan total biaya produksi dengan level strategy yang sebesar Rp 254,337,081.00.

Kata kunci : Peramalan, Perencanaan Agregat, Chase Strategy, Level Strategy
\end{abstract}

\begin{abstract}
Production planning and control is very important to minimize the occurrence of excess product inventory so that the demand season is low and vice versa there is a shortage of products during the high demand season. The purpose of this study is to determine and determine the amount of production with minimal costs at UD Dwi Putri Klungkung. This research was conducted on building products using an aggregate production planning system while the data used in this study were sales data for one year, production capacity, overtime costs, storage costs and labor costs. Based on the results of the study indicate that the estimated number of products produced during the next year is as many as 31,531 units, which are based on the exponential smoothing method. This method is used, because the exponential smoothing method gives results that have the smallest standard error with MAD value of 208.812, MSE value of 61843.5 and MAPE value of $7.97 \%$. Aggregate planning strategy with chase strategy produces a total production cost of Rp. 242,995,500.00, where the total cost lower, compared to the total production cost with a strategy level of Rp. 254,337,081.00.

Keywords: Forecasting, Aggregate Planning, Chase Strategy, Strategy Level
\end{abstract}




\section{PENDAHULUAN}

Umumnya payung merupakan alat yang sering kita gunakan pada musim hujan untuk melindungi diri dari guyuran hujan, selain itu payung juga digunakan untuk prasarana dalam upacara agama Hindu di Bali yang sering disebut dengan tedung. Tedung merupakan kerajinan yang familiar bagi masyarakat Hindu di Bali yang berfungsi sebagai prasarana dalam upacara agama Hindu di Bali, selain itu tedung juga digunakan sebagai ornamen hiasan hotel dan villa. Banyaknya hotel dan villa yang menggunakannya ditambah lagi mayoritas penduduk pulau Bali yang beragama Hindu membuat kerajinan tedung menjadi peluang bisnis yang menjanjikan.

Peluang bisnis merupakan kesempatan suata organisasi dalam menjual barang atau jasa kepada konsumen untuk mendapatkan laba. Untuk dapat memanfaatkan peluang bisnis yang optimal, diperlukan penerapan fungsi-fungsi manajemen, salah satunya yaitu perencanaan. Perencanaan merupakan suatu kegiatan pendahuluan atas proses produksi yang dilaksanakan dalam usaha mencapai tujuan yang diinginkan perusahaan (Magrib, 2014). Tujuan-tujuan yang diinginkan oleh setiap perusahaan yaitu dapat mencapai target perusahaan yang berupa laba yang maksimal dengan biaya yang paling miminum dan memenuhi permintaan konsumen tepat pada waktunya (Martha \& Setiawan, 2018)

Permintaan konsumen merupakan keinginan konsumen membeli suatu barang atau produk pada berbagai tingkat harga selama periode waktu tertentu yang di pengaruhi oleh beberapa faktor yaitu: harga produk, harga barang yang terkait, tingkat pendapatan, selera masyarakat, jumlah penduduk. Memenuhi permintaan konsumen diperlukan perencanaan produksi yang matang, karena perencanaan produksi berhubungan dengan penentuan volume produksi, ketepatan waktu penyelesaian, utilisasi kapasitas, dan pemerataan beban.

Perencanaan produksi merupakan suatu kegiatan untuk mendapatkan produk sesuai kebutuhan dua pihak yaitu perusahaan dan konsumen. Perencanaan produksi dapat diartikan sebagai suatu pernyataan rencana produksi secara keseluruhan yang memuat kesepakatan antara top management dengan bagian manufaktur yang disusun berdasarkan permintaan dan kebutuhan sumber daya perusahaan. Perencanaan produksi dalam suatu perusahaan terdiri dari tiga tingkatan perencanaan yang berdasarkan periode waktunya yaitu perencanaan jangka panjang, perencanaan jangka menengah dan perencanaan jangka pendek

Perencanaan jangka panjang merupakan perencanaan yang memiliki jangka waktu antara dua sampai lima tahun yang bersifat umum, global dan belum terperinci. Perencanaan jangka panjang biasanya berkaitan dengan perencanaan strategik, sedangkan perencanaan jangka menengah biasanya mempunyai jangka waktu antara beberapa bulan sampai tiga tahun. Perencanaan jangka menengah disusun berdasarkan perencanaan jangka panjang yang selanjutnya perlu dijabarkan lagi menjadi perencanaan jangka pendek yang memiliki jangka waktu satu hari sampai satu tahun

Perencanaan agregat (agregate planning) atau sering disebut dengan Penjadwalan agregat merupakan Perencanaan yang dikatagori kedalam perencanaan jangka menengah untuk merencanakan jadwal induk produksi selama satu tahun. Perencanaan agregat biasanya dilakukan oleh para manajer operasi yang 
bersangkutan dengan penentuan produksi, persediaan, dan tingkat tenaga kerja untuk memenuhi permintaan yang berfluktuasi (Takey \& Mesquita, 2006). Perencanaan agregat memberikan cara terbaik untuk memenuhi perkiraan permintaan dalam waktu 3-18 bulan ke depan, dengan menyesuaikan tingkat reguler dan lembur produksi, tingkat persediaan, tingkat tenaga kerja, subkontrak dan backorder tingkat, dan variabel terkontrol lainnya (Mortezaei, Zulkifli, Hong, \& Yusuff, 2013)

Permasalahan perencanaan agregat dapat diselesaikan dengan mempertimbangkan berbagai keputusan pilihan yang tersedia. Pilihan permintaan merupakan pilihan yang berupaya mengurangi perubahan pola permintaan selama periode perencanaan yang dapat dilakukan dengan cara dibawah ini, yakni : Mempengaruhi permintaan. Ketika permintaan rendah, sebuah perusahaan dapat mencoba untuk meningkatkan permintaan melalui iklan, promosi, kewiraniagaan, dan diskon seperti Perusahaan penerbangan dan hotel telah lama menawarkan diskon akhir pekan pada musim-musim sepi, Perusahaan telepon membebankan biaya yang lebih murah pada malam hari, dan pendingin udara dijual lebih murah pada waktu musim dingin. Bagaimana pun, bahkan iklan khusus, promosi, penjualan, dan penetapan harga tidak selalu mampu menyeimbangkan permintaan dengan kapasitas produksi.

Backorder selama periode permintaan tinggi. Backorder merupakan pesanan barang atau jasa yang diterima perusahaan tetapi tidak mampu (secara sengaja atau kebetulan) untuk dipenuhi pada saat itu. Backorder umumnya dilakukan oleh perusahaan yang memproduksi barang-barang yang kompleks dan bernilai tinggi seperti perusahaan kendaraan sepada motor. Bauran produk dan jasa yang melawan tren musiman merupakan teknik pelancar masalah aktif yang secara luas digunakan para pengusaha manufaktur adalah mengembangkan sebuah produk yang merupakan perpaduan dari barang counterseasonal. Contohnya adalah perusahaan yang membuat pemanas dan pendingin ruangan atau mesin pemotong rumput dan penyingkir salju.

Pilihan kapasitas merupakan pilihan yang tidak mengubah permintaan tetapi untuk mengantisipasi fluktuasi permintaan dapat dilakukan dengan cara mengubah kapasitas produksi perusahaan seperti Mengubah tingkat persediaan. Dengan meningkatkan persediaan selama periode permintaan rendah untuk memenuhi permintaan yang tinggi di masa mendatang. Konsekuensinya muncul biaya yang berkaitan dengan penyimpanan, Meragamkan jumlah tenaga kerja dengan merekrut (hire) atau memberhentikan (layoff). Dimana jumlah karyawan disesuaikan dengan tingkat produksi yang diinginkan. Konsekuensinya adalah moral pekerja dan produktivitas yang terpengaruh, serta munculnya biaya pelatihan dan perekrutan. Meragamkan tingkat produksi melalui lembur atau waktu kosong. Dalam pilihan ini jumlah tenaga kerja dijaga tetap konstan, namun waktu kerja yang diragamkan dengan mengurangi jam kerja ketika permintaan rendah, dan melakukan lembur ketika permintaan tinggi. Sekalipun begitu, ketika permintaan sedang tinggi, terdapat keterbatasan seberapa banyak lembur yang dapat dilakukan. Upah lembur membutuhkan lebih banyak uang, dan terlalu banyak lembur dapat membuat titik produktivitas pekerja secara keseluruhan merosot. Lembur juga dapat menyiratkan naiknya biaya overhead yang diperlukan untuk menjaga agar fasilitas dapat tetap 
berjalan. Subkontrak. Sebuah perusahaan dapat memperoleh kapasitas sementara dengan melakukan subkontrak selama periode permintaan tinggi. Pengertian dari subkontrak dalam bidang manufaktur adalah melakukan realokasi kebutuhan produksi antar perusahan agar memperlancar proses produksi. Pilihan ini memiliki beberapa kekurangan seperti: harga yang mahal ataupun kualitas dari pemasok subkontrak yang tidak sesuai. Penggunaan karyawan paruh waktu. Umumnya di sektor jasa dan untuk memenuhi kebutuhan tenga kerja yang tidak terampil.

Pada dasarnya tujuan dari perencanaan agregat yaitu untuk mengembangkan suatu rencana produksi secara menyeluruh yang dapat memenuhi permintaan pasar sesuai kapasitas yang ada dengan biaya yang minimal. Untuk memproleh biaya dan keuntungan yang optimal sesuai dengan tujuan perencanaan agregat, maka dalam melakukan perencanaan agregat perusahaan harus memilih beberapa strategi yang tepat bagi perusahaan. Strategi-strategi yang dapat digunakan untuk memenuhi permintaan pelanggan yang berfluktuatif yaitu: Chase Strategy dan Level Strategy (Sultana dkk., 2014)

Level strategy adalah rencana agregat di mana tingkat produksi tetap dari periode ke periode selama jangka waktu perencanaan agregat. Strategi perencanaan produksi dengan tingkat produksi yang konstan dari satu periode ke periode lainnya yang bertujuan untuk memenuhi rata-rata permintaan. Kemungkinan ke dua, level strategy ini menggunakan inventory dari adanya variasi dalam permintaan. Permintaan yang menurun mengakibatkan kelebihan produksi, maka kelebihan produksi tersebut disimpan sebagai persediaan untuk digunakan pada saat permintaan meningkat, sehingga pada strategi ini menimbulkan biaya simpan yang tinggi.

Chase strategy merupakan strategi yang mencoba untuk mencapai tingkat output untuk setiap periode yang memenuhi prediksi permintaan untuk periode tersebut. Strategi ini dapat terpenuhi dengan cara merubah tingkat tenaga kerja dengan mempekerjakan atau PHK, sub-kontrak, penggunaan lembur, penggunaan pekerja sementara, dll. Strategi ini cocok digunakan ketika biaya persediaan sangat tinggi. Namun, kebijakan semacam itu dapat menciptakan keresahan buruh. (Jayakumar dkk., 2017)

Memilih strategi yang tepat bagi perusahaan, diperlukan perhitungan perencanaan agregat. Perhitungan perencanaan agregat dapat dilakukan dengan menggunakan beberapa metode yaitu: Heuristik (Amri \& Harahap, 2012), Pemrograman dinamis , Simulasi (Gansterer, 2015), fuzzy multi-objective linear programming (Yerandee et al., 2011) dan Transportasi

Berdasarkan hasil penelitian yang dilakukan oleh Nisa \& Kusuma (2017). Menunjukkan bahwa dengan melakukan perencanaan agregat perusahaan dapat memenuhi permintaan konsumen dengan biaya produksi yang minimal. Hasil yang sama juga diproleh oleh Fajar \& Lestari (2017), Noegraheni \& Nuradli (2016) Cashiwan \& Yudoko (2016), Rahmadhani dkk. (2014), Octavianti, Setyanto, \& Tantrika (2013), Jamalnia et al. (2019), Cheraghalikhani et al. (2019), Talapatra, Saha, \& Islam, (2015), Gulsun et al. (2009), Li et al. (2013) Kalaf et al.(2015) Haslindah dkk. (2016), Indra (2017), Sawargo \& Mundari (2014), Carlos et al. (2006) dan Hairiyah \& Amalia (2018) 
UD Dwi Putri merupakan UMKM yang didirikan pada tahun 2010 di desa Sampalan Tengah, kecamatan Dawan, kabupaten Klungkung. Adapun jenis produk yang telah dibuat oleh UD Dwi Putri yaitu kerajinan tedung, yang dimana permintaan akan produk tersebut sering berfluktuasi yang dapat dilihat pada Tabel dibawah ini

Tabel 1.

Data Permintaan Tedung Bulan Maret 2018 - Februari 2019

\begin{tabular}{cc}
\hline Bulan (Tahun) & Jumlah (unit) \\
\hline Maret (2018) & 2.460 \\
April (2018) & 2.760 \\
Mei (2018) & 2.880 \\
Juni (2018) & 2.720 \\
Juli (2018) & 2.600 \\
Agustus (2018) & 2.300 \\
September (2018) & 2.480 \\
Oktober (2018) & 2.720 \\
November (2018) & 2.980 \\
Desember (2018) & 2.800 \\
Januari (2019) & 2.520 \\
Februari (2019) & 2.360 \\
\hline
\end{tabular}

Sumber:UD Dwi Putri, 2019

Berdasarkan Tabel 1. diketahui bahwa penjualan tedung UD Dwi Putri sangat berfluktuatif dengan penjualan tertinggi terjadi pada bulan November 2018 dengan jumlah penjualan sebanyak 2980 unit, sedangkan penjualan tedung UD Dwi Putri yang terendah terjadi di bulan Agustus 2018 dengan jumlah penjualan sebanyak 2300 unit. Untuk menyesuaikan kemampuan produksi dalam menghadapi permintaan tedung yang berfluktuatif maka diperlukannya perencanaan dan pengendaliaan produksi agregat yang matang.

Berdasarkan latar belakang yang telah diuraikan di atas, maka perumusan masalah dalam penelitian ini adalah Bagaimana perencanaan dan pengendalian produksi agregat pada usaha tedung UD Dwi Putri di Klungkung? Berkaitan dengan rumusan masalah penelitian, maka tujuan dalam melakukan penelitian ini adalah "Mengetahui perencanaan dan pengendalian produksi agregat pada usaha tedung UD Dwi Putri di Klungkung".

Secara teoritis, penelitian ini diharapkan dapat dijadikan bahan kajian atau tambahan pengetahuan dan wawasan untuk mendukung penelitian mendatang yang topiknya berkaitan dengan perencanaan agregat. Secara praktis, penelitian ini diharapkan mampu mengaplikasikan teori yang diproleh dalam perkuliahan pada perusahaan. Bagi perusahaan, hasil yang diproleh dalam penelitian ini dapat dijadikan pertimbangan di dalam merencanakan produksi yang datang.

Perencanaan produksi adalah penentu awal dari tindakan yang harus dilakukan di masa yang akan datang, apa yang harus dilakukan, berapa banyak dan kapan harus melakukannya. Perencanaan produksi dimulai dengan meramalkan permintaan secara tepat sebagai input utamanya. Peramalan permintaan biasanya dibuat untuk kelompok-kelompok produk secara kasar (tanpa memperhatikan perbedaan spesifikasi produk), khususnya selama periode waktu yang panjang. 
Perencanaan produksi adalah pernyataan rencana produksi ke dalam bentuk agregat. Perencanaan produksi ini merupakan alat komunikasi antara manajemen (top management) dan manufaktur. Selain itu juga perencanaan produksi dapat diartikan sebagai suatu perencanaan taktis yang bertujuan memberikan keputusan yang optimum berdasarkan sumber daya yang dimiliki perusahaan dalam memenuhi permintaan produksi yang dihasilkan. Sumber daya yang dimiliki adalah kapasitas mesin, tenaga kerja, teknologi yang dimiliki dan lainnya. Di dalam perencanaan produksi juga terdapat perencanaan agregat.

Perencanaan agregat adalah perencanaan kegiatan operasional untuk memberikan tingkat output yang harus dihasilkan sebuah fasilitas selama 3 hingga 18 bulan, agar sesuai dengan tingkat permintaan yang tidak pasti di masa depan dengan tetap mempertimbangkan minimalisasi total biaya operasi. Rencana ini harus konsisten dengan strategi jangka panjang manajemen puncak danm bekerja dengan sumber daya yang dialokasikan oleh keputusan strategis sebelumnya. Adapun tujuan dari perencanaan agregat adalah untuk membuat tingkat output secara keseluruhan untuk kebutuhan permintaan di masa depan yang berfluktuasi. Perencanaan agregat dihubungkan dengan keputusan bisnis lainnya seperti keuangan, pemasaran, dan manajemen sumber daya manusia.

Dalam kegiatan perencanaan agregat, peramalan dilakukan untuk menentukan jumlah permintaan terhadap suatu produk dan merupakan langkah awal dari proses perencanaan dan pengendalian produksi. Tujuan peramalan dalam kegiatan produksi adalah untuk ketidakpastian, sehingga diperoleh suatu perkiraan yang mendekati keadaan yang sebenernya.

Peramalan merupakan suatu perkiraan kegiatan pada masa yang akan datang. Salah satu syarat utamanya adalah tersedianya data historis / masa lalu yang dapat dipercaya yang digunakan sebagai alat untuk menentukan nilai-nilai fungsi atau persamaan pada peramalan. Peramalan penting dilakukan dalam penyusunan Aggregate Planning sebab data hasil peramalan nantinya digunakan sebagai input dalam penyusunan Aggregate Planning. Metode peramalan yang dilakukan untuk mengurangi suatu ketidakpastian dalam memenuhi permintaan suatu produk. Metode-metode tersebut yaitu: Moving average dapat digunakan sebagai alat peramal.

Pada kasus tertentu, moving average lebih baik daripada metode least square. Moving average hanya menggunakan rata-rata data permintaan masa lampau dalam jumlah yang telah ditentukan sebelumnya. Untuk setiap periode, moving average yang baru dihitung dengan cara mengabaikan permintaan pada periode yang paling awal dan memasukkan permintaan pada periode paling akhir. Setiap metode dalam peramalan produksi (forecasting) yang bersifat kuantitatif memerlukan adanya penyesuaian terhadap fluktuasi permintaan produk. Didalam exponential smoothing kita berusaha menambahkan suatu faktor yang disebut smoothing constan dan diberikan simbol alpha. Faktor penambahan tersebut biasanya langsung dihubungkan dengan data penjualan dari tahun yang paling akhir.

Pemilihan metode dalam peramalan sangat penting dilakukan, untuk memproleh peramalan yang tepat dan akurat. Pemilihan metode paramalan dilakukan dengan memilih metode-metode paramalan yang menghasilkan standart error yang paling kecil. Hasil peramalan dengan MAD, MAPE, dan MSE terkecil 
atau kesalahan peramalan terkecil (standart error of the estimate) digunakan sebagai bahan untuk merencanakan perencanaan dan pengendalian produksi agregat.

Pengendalian adalah penemuan dan penerapan cara dan peralatan untuk menjamin bahwa rencana telah dilaksanakan sesuai dengan apa yang ditetapkan Sedangkan yang dimaksud dengan proses produksi adalah kegiatan dalam suatu perusahaan yang di arahkan untuk menjamin kontinuitas dan aktifitas untuk menyelesaikan produk sesuai dengan bentuk dan waktu yang diinginkan dalam batas-batas yang direncanakan.pengendalian proses produksi merupakan kegiatan atau proses untuk menjamin agar barang yang diproduksi sesuai dengan jumlah, desain dan biaya yang telah direncanakan. Fungsi pengendalian proses produksi adalah perencanaan, penentuan urutan kerja, penentuan waktu kerja, pemberian perintah kerja, dan tindak lanjut dalam pelaksanaan

Perencanaan produksi dalam suatu perusahaan terdiri dari tiga tingkatan perencanaan yang berdasarkan periode waktunya 1) Jangka panjang (long-term), untuk perencanaan lebih dari 1 tahun. Dimana sumber daya produktif (seperti gedung, peralatan atau fasilitas) membutuhkan waktu yang lama untuk diperoleh atau dibuang, perencanaan kapasitas jangka panjang membutuhkan partisipasi dari manajemen puncak, karena keputusan yang diambil berkenaan dengan fungsi penambahan fasilitas dan peralatan yang memiliki lead time panjang. 2) Jangka menengah (medium-term), perencanaan bulanan atau kwartalan untuk 3 hingga 18 bulan ke depan. Di sini, kapasitas dapat divariasikan dengan memanfaatkan sumber daya yang tersedia, yaitu dengan menggunakan alternatif seperti penambahan jumlah karyawan atau jumlah shift, atau dapat dilakukan subkontrak dan dapat juga menggunakan persediaan. 3) Jangka pendek (short-term), perencanaan kurang dari 1 bulan. Ini terikat dengan proses penjadwalan tugas dan karyawan secara harian atau mingguan atau pengalokasian mesin, dan membutuhkan penyesuaian untuk mengeliminasi perbedaan antara output aktual dengan yang direncanakan.

Biaya-biaya yang berkaitan dengan Perencanaan Agregat menurut Schroeder adalah 1) Hiring cost merupakan biaya yang terdiri dari biaya perekrutan, penyaringan dan pelatihan tenaga kerja baru agar menjadi tenaga kerja yang produktive sepenuhnya. Semakin tinggi keahlian yang diperlukan semakin tinggi pula biaya yang harus dikeluarkan. Sedangkan biaya penghentian (Layoff Costs) meliputi biaya PHK, tunjangan pekerjaan. 2) Overtime cost atau biaya jam kerja lembur biasanya lebih besar dari biaya jam kerja reguler. Sedangkan biaya jam kerja reguler (Undertime Costs) dilihat dari penggunaan tenaga kerja yang berkurang dari produktivitas penuh. 3) Inventory - Carrying cost Merupakan biaya penyimpanan

Perencanaan agregat dapat dilakukan dengan melakukan pilihan atas 2 strategi, yaitu strategi Chase dan strategi penjadwalan bertingkat (Level strategy). Chase strategy merupakan strategi yang mencoba untuk mencapai tingkat keluaran dari setiap periode yang memenuhi ramalan permintaan pada periode tersebut. Strategi ini bisa dipenuhi dengan berbagaicara. Contohnya manajer operasi bisa mengubah tingkat tenaga kerja dengan merekrut atau memberhentikan tenaga kerja, atau bisa mengubah-ubah keluaran dengan waktu lembur, waktu kosong atau subkontrak. 
Level strategy merupakan strategi perencanaan agregat dengan tingkat produksi yang konstan dari satu periode ke periode. Strategi ini bisa dilakukan dengan mengubah tingkat persediaan dimana manajer bisa meningkatkan persediaan selama periode permintaan yang rendah untuk memenuhi permintaan yang tinggi pada masa mendatang.

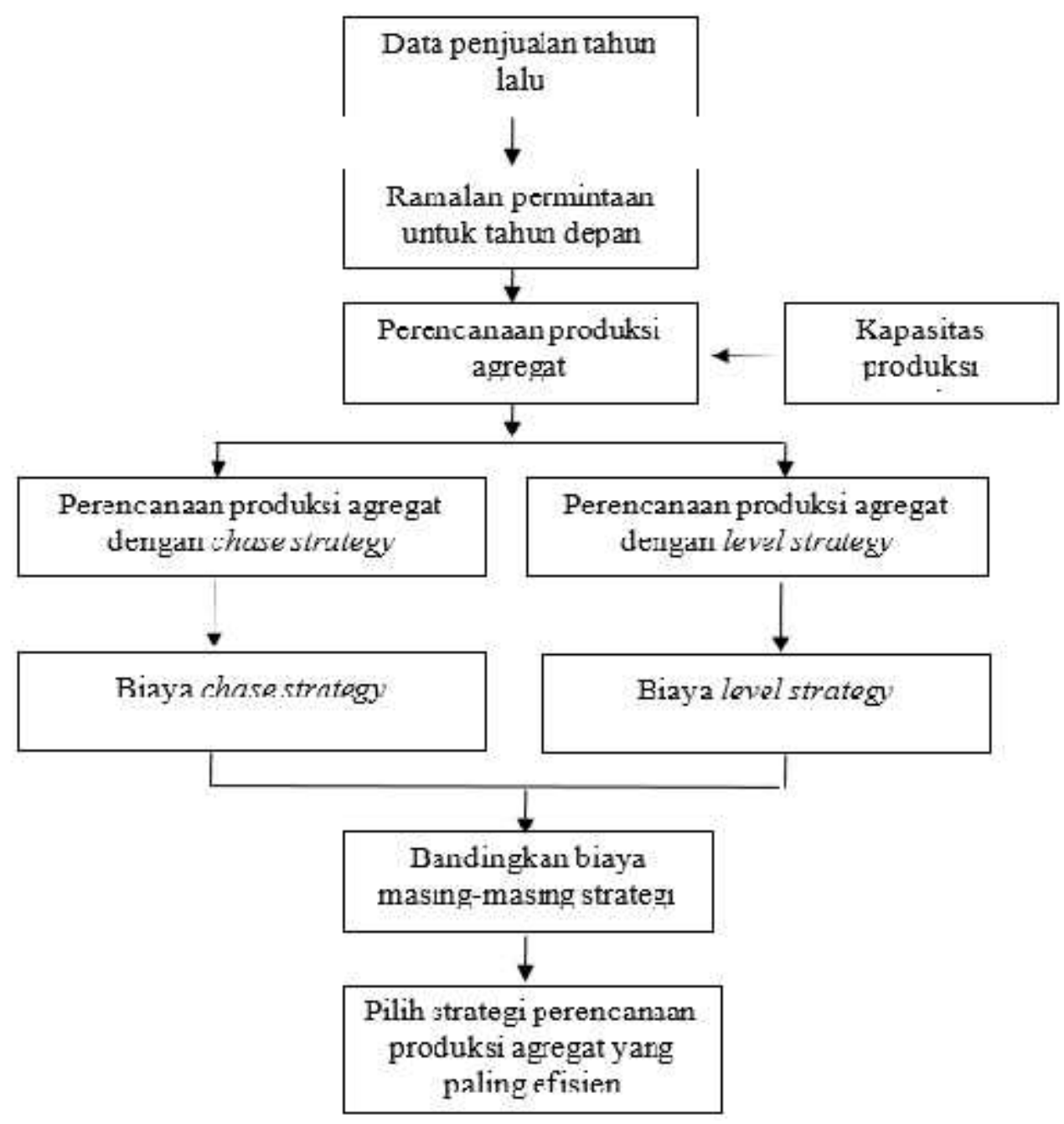

Gambar 1. Kerangka Konseptual

\section{METODE PENELITIAN}

Penelitian ini termasuk kedalam penelitian deskriptif dengan mengunakan pendekatan kuantitatif. Penelitian deskriptif merupakan penelitian yang dilakukan untuk mengetahui variabel mandiri, baik satu variabel maupun lebih dari satu variabel (variabel yang berdiri sendiri) tanpa membuat perbandingan atau mencari hubungan satu dengan yang lainya.

Penelitian ini dilakukan pada UD Dwi Putri yang memproduksi tedung khas Bali berlokasi di Br Pakel, Desa Sampalan Tengah, Kecamatan Dawan, Kabupaten Klungkung. Perusahaan ini dipilih karena permintaan produk dari UD Dwi Putri 
yang berfluktuatif dan perencanaan produksi yang kurang optimal, sehingga sering terjadi permasalahan kelebihan persediaan produk pada saat permintaan yang sedikit, sebaliknya terjadi kekurangan persediaan produk pada saat permintaan yang meningkat.

Objek dalam penelitian ini adalah perencanaan dan pengendalian produksi agregat pada UD Dwi Putri. Produk yang akan dianalisis dalam penelitian ini adalah produk tedung. Variabel-variabel yang dianalisis sesuai dengan masalah utama dan tujuan yang ingin dicapai dalam penelitian ini adalah: Perkiraan permintaan, Persediaan awal, Kapasitas produksi, Biaya perencanaan produksi agregat.

Perkiraan permintaan merupakan jumlah perkiraan permintaan produk selama bulan Maret 2019 sampai bulan Februari 2020. Persediaan awal merupakan persediaan barang yang tersedia di gudang pada awal bulan. Persediaan awal dapat dilihat pada laporan persediaan. Kapasitas produksi merupakan kemampuan perusahaan untuk memproduksi produk dalam satu bulan

Biaya perencanaan produksi agregat merupakan biaya-biaya yang dikeluarkan ketika perusahaan melakukan perencanaan agregat, adapaun biaya tersebut yaitu : Overtime cost merupakan biaya-biaya yang dikeluarkan perusahaan, apabila tenaga kerja bekerja diluar jam kerja normal yang dihitung per unit Inventory carrying cost merupakan biaya-biaya yang dikeluarkan oleh perusahaan ketika perusahaan menyimpan kelebihan dari produk-produk yang diproduksi dengan permintaan pada bulan tersebut. Biaya ini dihitung per unit pertahun. Stockout cost merupakan kerugian yang timbul ketika perusahaan kehabisan persediaan pada saat permintaan produk tinggi yang disesuaikan berdasarkan dari jumlah kehilangan laba yang diproleh per unit produk.

Jenis data yang digunakan dalam penelitian ini adalah data kuantitatif dan data kualitatif. Data kuantitatif yakni data yang berupa angka yang mempunyai satuan hitung, antara lain data penjualan produk tahun lalu, data persediaan awal, data kapasitas produksi perbulan, jumlah tenaga kerja, waktu produksi, biaya overtime, biaya produksi, biaya subkontrak dan biaya penyimpanan. Sedangkan data kualitatif pada penelitian ini berupa jenis bahan baku dan sejarah perusahaan.

Data skunder yaitu data yang mengacu pada informasi yang dikumpulkan dari dokumentasi perusahaan. Data-data dokumentasi perusahaan meliputi data penjualan tahun lalu, data aktual persediaan, kapasitas produksi perbulan, jumlah tenaga kerja, waktu produksi, biaya overtime, biaya produksi, biaya stockout dan biaya penyimpanan.

Metode pengumpulan data menggunakan 1) Wawancara merupakan teknik pengumpulan data dengan melakukan tanyajawab secara langsung dengan responden yang terdiri dari pemilik perusahaan. Wawancara dilakukan sesuai atau berpatokan dengan pedoman wawancara atau daftar pertanyaan yang diharapkan mendapat penjelasan tentang hal-hal yang relevan mengenai data yang dibutuhkan. 2) Observasi adalah pengamatan dan pencatatan secara teliti dan sistematis atas mengenai kondisi produksi, kondisi persediaan dan catatan-catatan pada pesediaan. Observasi dilakukan dengan melihat langsung, mendengar dan mengamati persediaan barang yang diteliti dan dipergunakan untuk menyesuaikan data yang diperoleh. 
Teknik yang digunakan untuk menganalisis data pada penelitian ini yaitu teknik deskriptif yang menggambarkan atau menjelaskan proses peramalan sampai dengan perencanaan produksi agregat. Adapun langkah-langkah untuk menganalisis data pada penelitian ini adalah: 1) Membuat peramalan permintaan untuk bulan Maret 2019 sampai bulan Februari 2020 menggunakan metode peramalan Moving Average, dan Eksponential Smoothing dengan bantuan software POMQM for Windows Version 5.2. 2) Memilih hasil peramalan yang mempunyai tingkat kesalahan yang paling kecil. 3) Membuat perencanaan produksi agregat dengan metode grafik menggunakan hasil peramalan yang mempunyai tingkat kesalahan terkecil sebagai inputnya. 4) Mengembangkan beberapa alternatif strategi perencanaan agregat dan menghitung jumlah biaya yang dihasilkan dari beberapa alternatif tersebut.

\section{HASIL DAN PEMBAHASAN}

UD Dwi Putri merupakan perusahaan yang bergerak dibidang kerajinan yang menjual kerajinan tedung. UD Dwi Putri berlokasi di banjar Pakel, desa Sampalan Tengah, Klungkung, Bali yang didirikan oleh Bapak Gede Putrawan dengan jumlah karyawan 10 orang. UD Dwi Putri berawal dari usaha kerajinan kerangka tedung Bapak Gede Putrawan pada tahun 2010 yang menjual dan memproduksi berbagai jenis kerangka tedung dengan modal awal pada saat itu sebesar Rp. 10.000.000,-.

Pada tahun 2010 UD Dwi Putri mulai memperkerjakan empat karyawan untuk membantu kegiatan usahanya dalam membuat kerangka tedung. Pada tahun 2013 perusahaan yang dipimpin oleh Bapak Gede Putrawan ini sempat mengalami penurunan penjualan kerangka tedung sehingga pada tahun 2014 Bapak Gede Putrawan mulai mencari peluang usaha lain, mencari pasar, dan mempersiapkan perusahaan. Pada tahun 2015 perusahaan sudah mulai efektif dalam memproduksi kerajinan tedung yang dipasarkan hanya di wilayah Klungkung saja. Kemudian berangsur-angsur perusahaan mengembangkan wilayah pemasarannya ke Gianyar, Buleleng, Negara, Badung dan Tabanan. Berdasarkan wawancara dengan pemilik UD Dwi Putri permintaan produk tedung dari UD Dwi Putri yang selalu berfluktuatif, sehingga sering terjadi kelebihan persediaan produk pada saat permintaan sedikit, sebaliknya terjadi kekurangan persediaan produk pada saat permintaan meningkat.

Permasalahan ini dapat mengakibatkan timbulnya biaya perencanaan agregat yang kurang optimal sehingga objek dalam penelitian ini yaitu perencanaan dan pengendalian produksi agregat tedung. Data permintaan yang digunakan adalah data permintaan tedung selama satu tahun, yaitu, mulai dari Maret 2018 - Februari 2019. Berikut ini adalah tabel permintaan produk tedung selama satu tahun.

Persediaan awal merupakan salah satu informasi yang dibutuhkan dalam menyusun perencanaan dan pengendaliaan produksi agregat yang terdiri dari persediaan barang jadi yang tersedia di gudang pada awal bulan. Berdasarkan hasil wawancara terhadap pemilik UD Dwi Putri jumlah persediaan awal produk tedung pada bulan Maret 2019 yaitu sebanyak 120 unit

Kapasitas produksi merupakan kemampuan perusahaan untuk memproduksi tedung dalam satu bulan yang dicari dengan menggunakan rumus: $k=$ ja $k \quad \div w \quad b \quad \times h a k \quad$ Berdasarkan rumus tersebut, maka 
data yang diperlukan untuk mencari kapasitas tersebut adalah: Jam kerja merupakan waktu yang digunakan untuk melakukan pekerjaan. Jam kerja yang dilakukan oleh UD Dwi Putri yaitu 8 jam/ hari. Waktu baku merupakan waktu yang digunakan untuk memproduksi satu unit tedung. Berdasarkan dari hasil wawancara waktu yang digunakan dalam memproduksi satu unit tedung yaitu 4.8 menit/ unit, sehingga dalam satu jam UD Dwi Putri dapat memproduksi tedung sebanyak 12.5 unit/jam. Hari kerja merupakan hari yang digunakan orang untuk bekerja. Berikut ini tabel hari kerja yang diterapkan oleh UD Dwi Putri

Tabel 2.

Data Permintaan Tedung Bulan Maret 2018 - Februari 2019

\begin{tabular}{cc}
\hline Bulan (Tahun) & Jumlah (unit) \\
\hline Maret (2018) & 2.460 \\
April (2018) & 2.760 \\
Mei (2018) & 2.880 \\
Juni (2018) & 2.720 \\
Juli (2018) & 2.600 \\
Agustus (2018) & 2.300 \\
September (2018) & 2.480 \\
Oktober (2018) & 2.720 \\
November (2018) & 2.980 \\
Desember (2018) & 2.800 \\
Januari (2019) & 2.520 \\
Februari (2019) & 2.360 \\
\hline
\end{tabular}

Sumber : UD Dwi Putri, 2018-2019

Tabel 3.

Daftar Hari Kerja

\begin{tabular}{cl}
\hline Bulan & Jumlah \\
\hline Maret & 27 hari \\
April & 26 hari \\
Mei & 27 hari \\
Juni & 26 hari \\
Juli & 27 hari \\
Agustus & 27 hari \\
September & 26 hari \\
Oktober & 27 hari \\
November & 26 hari \\
Desember & 27 hari \\
Januari & 27 hari \\
Februari & 24 hari \\
\hline
\end{tabular}

Sumber : UD Dwi Putri, 2019

Berdasarkan dari data waktu baku, jam kerja dan hari kerja di atas maka dapat cari jumlah kapasitas produksi dalam satu bulan dapat dilihat pada tabel 4 dibawah ini.

Biaya perencanaan produksi agregat merupakan informasi penting yang diperlukan dalam melakukan perencanaan produksi agregat, berdasrkan hasil wawancara terhadap pemilik dari UD Dwi Putri biaya perencanaan produksi agregat terdiri dari Overtime cost merupakan biaya yang dikelarkan perusahaan ketika perusahaan melemburkan tenaga kerja untuk memenuhi permintaan yang 
tinggi. Berdasarkan wawancara terhadap UD Dwi Putri Overtime cost yang diberikan kepada tenaga kerja yang lembur yaitu sebesar Rp 15.000 /jam/orang, sehingga Overtime cost perunit adalah Rp 12.000/unit

Tabel 4.

Tabel Perhitungan Kapasitas Produksi Dalam Satu Bulan

\begin{tabular}{ccccc}
\hline Bulan & $\begin{array}{c}\text { Jam kerja }(8 \\
\text { Jam=480 menit })\end{array}$ & $\begin{array}{c}\text { Waktu baku (1 } \\
\text { unit=4.8 menit) }\end{array}$ & $\begin{array}{c}\text { Jumlah hari } \\
\text { kerja }\end{array}$ & $\begin{array}{c}\text { Kapasitas per } \\
\text { bulan (unit) }\end{array}$ \\
\hline Maret & 480 & 4.8 & 27 & 2700 \\
April & 480 & 4.8 & 26 & 2600 \\
Mei & 480 & 4.8 & 27 & 2700 \\
Juni & 480 & 4.8 & 26 & 2600 \\
Juli & 480 & 4.8 & 27 & 2700 \\
Agustus & 480 & 4.8 & 27 & 2700 \\
September & 480 & 4.8 & 26 & 2600 \\
Oktober & 480 & 4.8 & 27 & 2700 \\
November & 480 & 4.8 & 26 & 2600 \\
Desember & 480 & 4.8 & 27 & 2700 \\
Januari & 480 & 4.8 & 27 & 2700 \\
Februari & 480 & 4.8 & 24 & 2400 \\
\hline
\end{tabular}

Sumber: Data Primer diolah, 2019

Inventory carrying cost merupakan biaya yang digunakan untuk menyimpan suatu barang/produk yang dihitung berdasarkan presentase harga dari produk yang disimpan di gudang tiap bulannya. Berdasarkan wawancara, presentase dan biaya penyimpanan pada penelitian ini yaitu; 1) Biaya fasilitas penyimpanan : 5\% dari harga pokok 2) Biaya kerusakan: $2 \%$ dari harga pokok 3) Biaya modal: 0.4\% dari harga pokok dan Total biaya penyimpanan adalah $7.4 \%$ dari harga pokok. Dari total biaya penyimpanan tersebut dapat diketahui biaya penyimpanan yang dibutuhkan untuk satu unit produk yaitu sebesar Rp 1.999/unit/tahun

Stockout cost merupakan biaya yang terjadi karena perusahaan kehabisan stock produk untuk memenuhi permintaan. Stockout cost dapat dicari dengan mengurangi harga jual produk dengan harga pokok produk, sehingga stockout cost pada produk tedung UD Dwi Putri yaitu sebesar Rp 5.486/unit. Adapun datadata yang diperlukan dalam mencari Stockout cost yaitu: Harga jual produk merupakan harga yang diberikan kepada konsumen untuk memproleh produk tersebut. Berdasarkan hasil wawancara harga jual untuk satu unit tedung yaitu sebesar Rp. 32.500/ unit.

Harga pokok merupakan biaya yang digunakan untuk memproduksi satu unit produk tedung yang terdiri dari: Regular time cost merupakan biaya yang di keluarkan untuk memperkerjakan tenaga kerja pada waktu jam kerja biasa. Besarnya Regular time cost yang diberikan UD Dwi Putri terhadap tenaga kerja yaitu sebesar Rp 7.650/unit

Biaya overhead pabrik merupakan biaya produksi yang tidak masuk kedalam biaya bahan baku atau biaya tenaga kerja langsung. Biaya overhead pabrik pada 
penelitian ini terdiri dari : Biaya tagihan listrik: Rp. 500.000/bulan, Biaya pulsa hp: Rp 100.000/bulan dan Total biaya overhead : Rp 600.000/ bulan. Dari total biaya overhead pabrik tersebut, maka dapat dihitung biaya overhead pabrik untuk satu unit tedung yaitu sebagai berikut: $\mathrm{BOP}=600.000 / 2.600=230.77 /$ unit/bulan. Biaya bahan baku merupakan biaya yang digunakan untuk memproleh bahan baku dari produk yang diproduksi. Berikut ini tabel daftar harga bahan baku produk tedung per unit

Tabel 5.

Daftar Harga Bahan Baku Per Unit

\begin{tabular}{|c|c|c|}
\hline Nama bahan baku & Harga / Unit & \\
\hline \multicolumn{3}{|l|}{ Bahan baku } \\
\hline Bambu & Rp 1,000.00 & \\
\hline Kayu & Rp 1,282.05 & \\
\hline Benang & Rp 2,159.09 & \\
\hline Kain & Rp 6,166.67 & \\
\hline Pati & $\operatorname{Rp} 6,000.00$ & \\
\hline Total bahan baku & & Rp 16,607.81 \\
\hline \multicolumn{3}{|l|}{ Bahan penolong } \\
\hline Kawat & $\operatorname{Rp} 250.00$ & \\
\hline Aluminium & Rp 316.67 & \\
\hline Cat Kembang & Rp 126.67 & \\
\hline Cat Aga & $\operatorname{Rp} 250.00$ & \\
\hline Cat Hooker & Rp 100.00 & \\
\hline Lem & $\operatorname{Rp} 60.00$ & \\
\hline Paku & $\operatorname{Rp} 422.22$ & \\
\hline Total bahan penolong & & Rp $\quad 1,525.55$ \\
\hline Total biaya bahan baku & & Rp $18,133.36$ \\
\hline
\end{tabular}

Sumber: Data Primer diolah, 2019

Berdasarkan data diatas maka dapat dihitung harga pokok unutk satu unit produk tedung di UD Dwi Putri yaitu sebesar Rp 27,014.13.

Maksimum lembur merupakan jumlah jam maksimum dalam melakukan lembur dalam satu hari, maksimum jam lembur yang dilakukan oleh UD Dwi Putri yaitu 2 jam/hari. Jumlah unit yang dihasilkan selama satu kali lembur yaitu 25 unit/ hari.

Berdasarkan data permintaan yang ada pada Tabel 2. dibuatlah grafik menggunakan bantuan software Microsoft Excel untuk dapat lebih mudah diketahui pola yang terjadi pada data permintaan produk. Berikut adalah gambar grafik dari data permintaan produk tedung bulan Maret 2018 -Februari 2019

Berdasarkan grafik dalam Gambar 2. diketahui pola permintaan produk tedung yang berfluktuatif, maka diperlukan suatu peramalan. Peramalan yang akan dilakukan adalah peramalan permintaan untuk bulan Meret 2019 sampai bulan Februari 2020 dengan teknik peramalan yang digunakan adalah Moving Average dan Exponential Smoothing. Berikut ini adalah tabel yang menyajikan perbandingan nilai MAD, MSE, dan MAPE dari hasil peramalan permintaan kedua metode. 


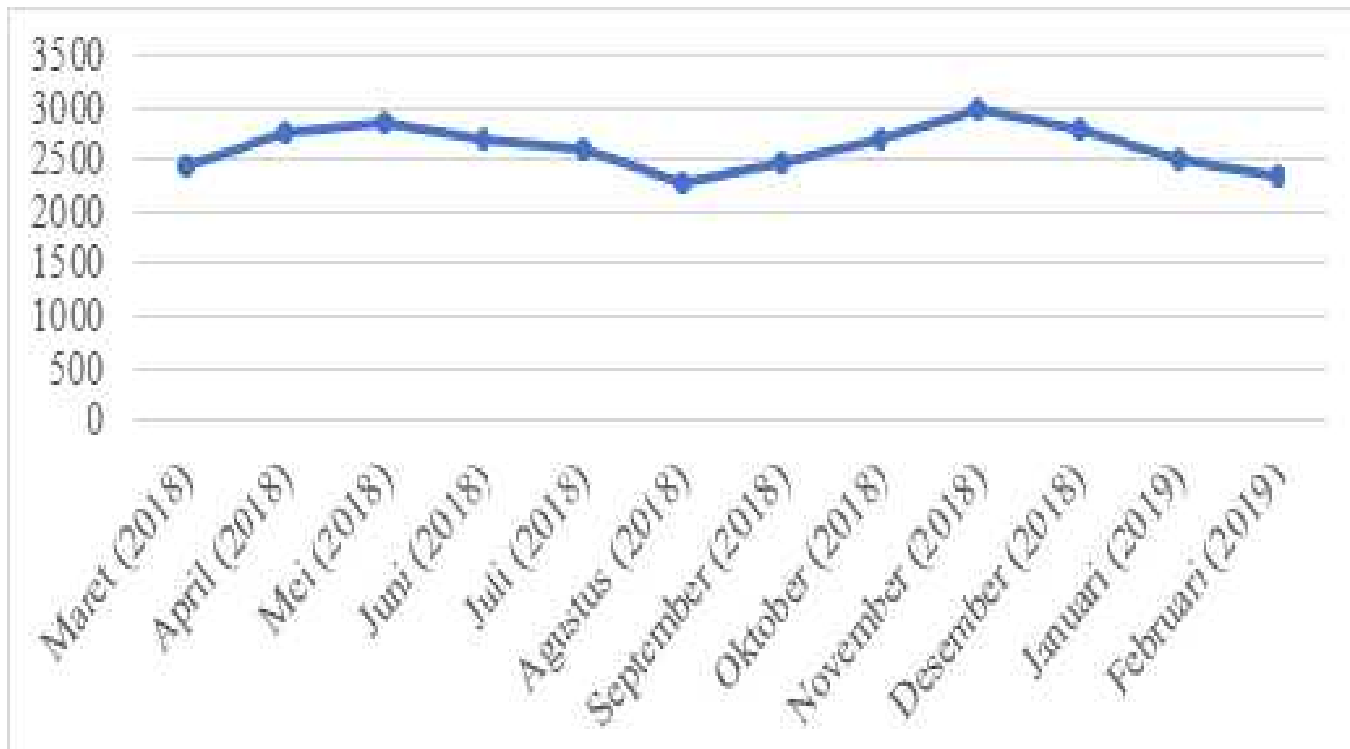

Gambar 2. Pola Data Permintaan Produk Tedung Bulan Maret 2018 Februari 2019

Sumber: Data Primer diolah, 2019

Tabel 6.

Perbandingan Nilai MAD, MSE, dan MAPE Metode Moving Average dan Exponential Smoothing.

\begin{tabular}{lccc}
\hline Metode & MAD & MSE & MAPE \\
\hline Moving Average & 248.148 & $88,172.86$ & $9.681 \%$ \\
Exponential Smoothing & 208.812 & $61,843.5$ & $7.97 \%$ \\
\hline
\end{tabular}

Sumber: Data Primer diolah, 2019

Dari hasil perhitungan peramalan permintaan dengan bantuan software POMQM for Windows Version 5.2 menunjukkan bahwa hasil peramalan dengan menggunakan exponential smoothing lebih baik dibandingkan dengan metode moving average, karena memiliki kesalahan peramalan terkecil yang ditunjukkan dengan nilai MAD, MSE, dan MAPE.

Analisis perencanaan agregat pada penelitian ini menggunakan metode grafik dengan strategi chase dan level. Berikut hasil peramalan bulan Maret 2019 sampai bulan Februari 2020 menggunakan metode exponential smoothing yang disajikan dalam tabel berikut.

Berdasarkan Tabel 7. diketahui jumlah perkiraan permintaan bulan maret 2019 sampai bulan Februari 2020 sebanyak 31.531 unit, sehingga padat dilakukan perhitungan perencanaan agregat menggunakan metode grafik. Berikut gambar grafik permintaan dan rata-rata permintaan per bulan.

Berdasarkan Gambar 3 menunjukkan bahwa ramalan permintaan berbeda dengan rata-rata permintaan perbulan. Permintaan pada bulan Maret, Agustus, September, Januari dan Februari berada dibawah permintaan rata-rata perbulan sedangkan pada bulan April, Mei, Juni, Oktober, November dan Desember berada 
diatas permintaan rata-rata perbulan. Berikut strategi yang dapat digunakan untuk memenuhi ramalan permintaan yaitu chase strategy dan level strategy.

Tabel 7.

Peramalan Permintaan Tedung Bulan Maret 2019 Sampai Bulan Februari 2020

\begin{tabular}{cc}
\hline $\begin{array}{c}\text { Bulan } \\
\text { (tahun) }\end{array}$ & Jumlah Permintaan (unit) \\
\hline Maret (2019) & 2.509 \\
April (2019) & 2.460 \\
Mei (2019) & 2.610 \\
Juni (2019) & 2.745 \\
Juli (2019) & 2.732 \\
Agustus (2019) & 2.666 \\
September (2019) & 2.483 \\
Oktober (2019) & 2.482 \\
November (2019) & 2.601 \\
Desember (2019) & 2.790 \\
Januari (2020) & 2.795 \\
Februari (2020) & 2.658 \\
Total & 31.531 \\
\hline
\end{tabular}

Sumber: Data Primer diolah, 2019

\section{Permintaan dan Rata-rata Permintaan}

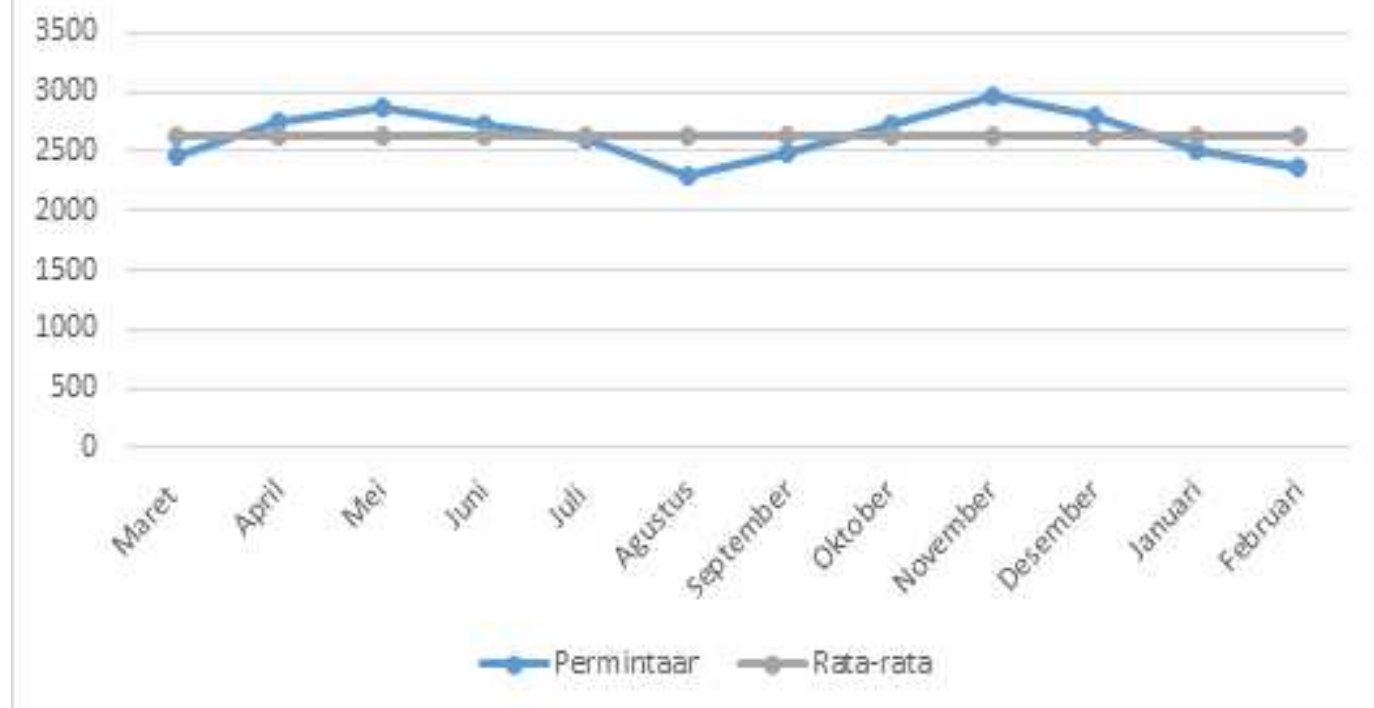

Gambar 3. Grafik Permintaan dan Rata-rata permintaan

Perencanaan agregat dengan chase strategy merupakan perencanaan agregat yang mencoba untuk mencapai tingkat keluaran dari setiap periode yang memenuhi ramalan permintaan pada periode tersebut dengan menggunakan regular time dan overtime. Berikut gambar grafik perencanaan agregat dengan menggunakan chase strategy 


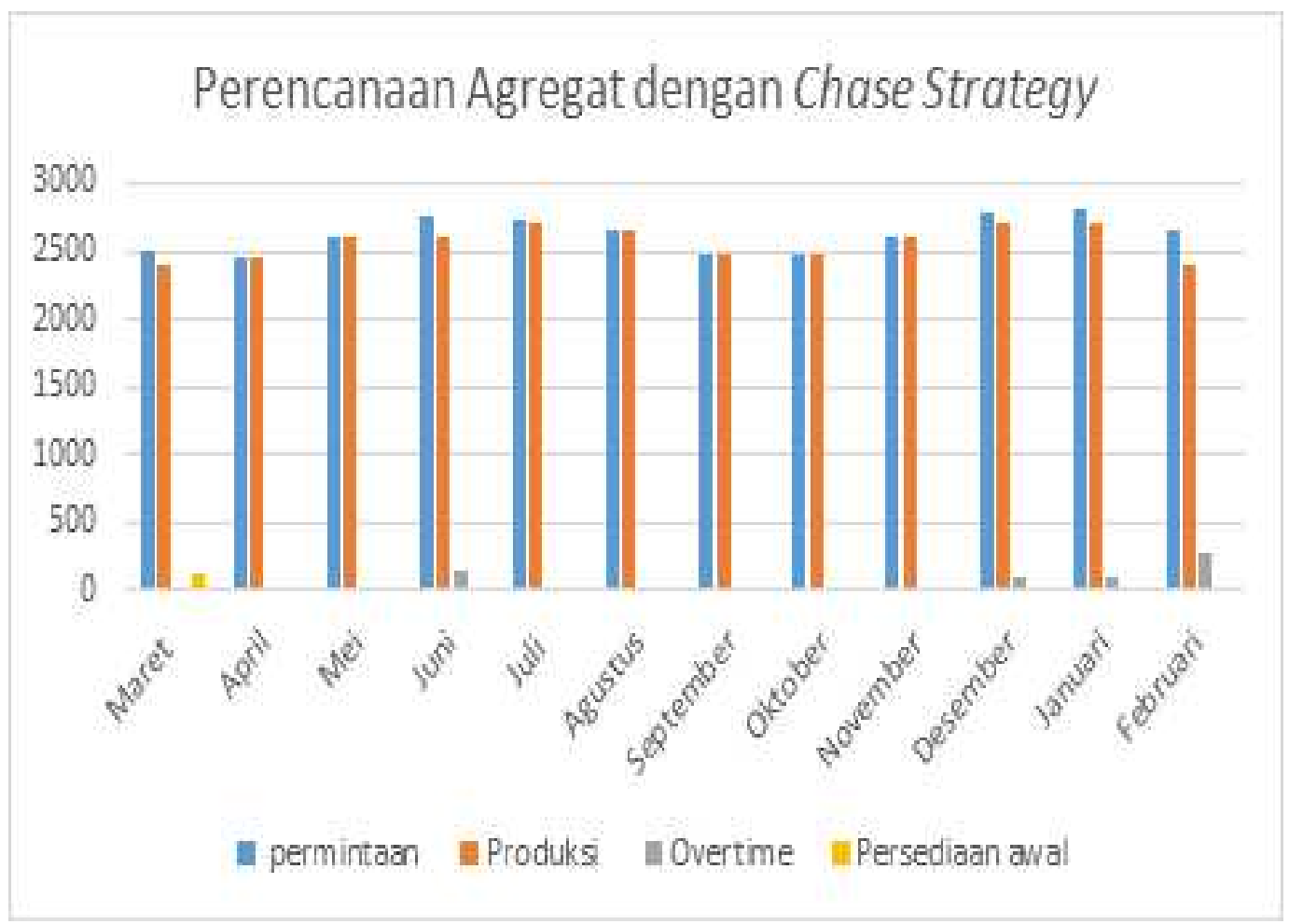

\section{Gambar 4. Grafik Perencanaan Agregat dengan Chase Strategy}

Berdasarkan Gambar 4. dapat diketahui dalam memenuhi permintaan pada bulan April, Mei, Agustus, September dan Oktober dilakukan dengan menggunakan produksi regular. Permintaan pada bulan Juni, Juli, November, Desember, Januari dan Februari dipenuhi dengan menggunakan produksi regular dan overtime, sedangkan pada bulan Maret dipenuhi dengan menggunakan persediaan awal dan produksi regular, sehingga biaya produksi pada strategi ini yaitu Regular cost Rp 235.543.500,00 dan Overtime cost Rp 7.4520.000,00 menjadi Rp 242.995.500,00

Perencanaan agregat dengan level strategy merupakan perencanaan agregat dengan tingkat produksi yang konstan dari satu periode ke periode. Perencanaan agregat dengan level strategy bisa dilakukan dengan mengubah tingkat persediaan dimana manajer bisa meningkatkan persediaan selama periode permintaan yang rendah untuk memenuhi permintaan yang tinggi pada masa mendatang. Berikut gambar perencanaan agregat dengan level strategy.

Berdasarkan Gambar 5 dapat diketahui pada bulan Maret, April, Mei, Agustus, September, dan Oktober, terjadi kelebihan produksi sehingga pada bulan tersebut adanya penambahan inventory sedangkan permintaan pada bulan Juni, Juli, November, Januari, dan Februari terjadi kekurangan produksi sehingga inventory pada bulan sebelumnya diambil untuk memenuhi permintaan pada bulan Februari, sehingga biaya produksi pada strategi ini yaitu Regular cost adalah $\mathrm{Rp}$

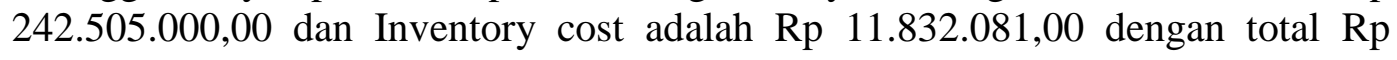
254.337.081,00 


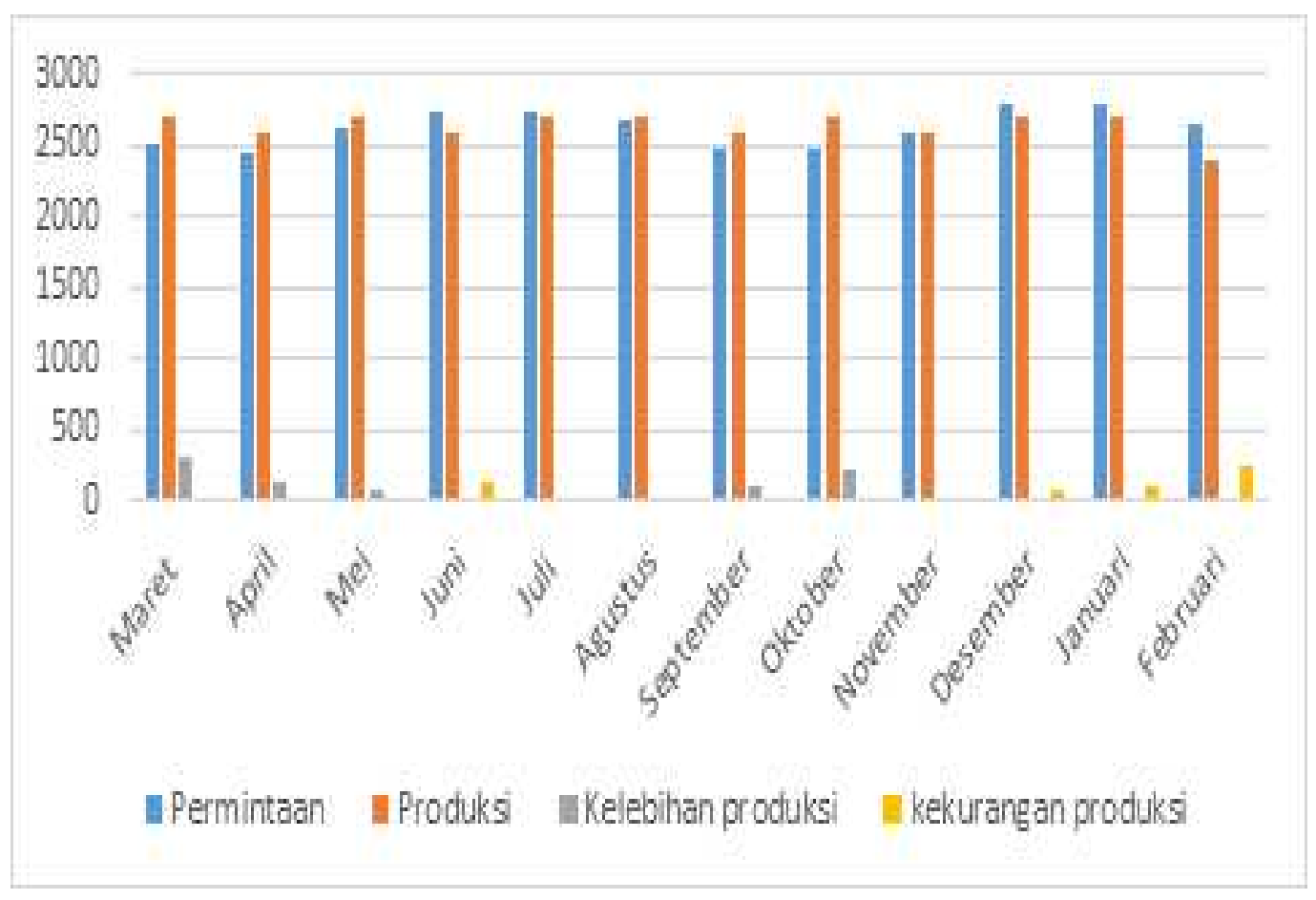

\section{Gambar 5. Grafik Perencanaan Agregat dengan Level Strategy}

Berdasarkan perhitungan perencanaan agregat dengan chase strategy menunjukkan biaya perencanaan yang paling optimal dibandingkan dengan level strategy yang dapat dilihat pada tabel dibawah ini.

Tabel 8.

Perbandingan biaya perencanaan agregat dengan menggunakan chase strategy dan level strategy.

\begin{tabular}{lc}
\hline Strategi & Total Biaya \\
\hline Chase strategy & Rp 242,995,500.00 \\
Level strategy & Rp $254,337,081.00$ \\
\hline
\end{tabular}

Sumber: Data Primer diolah, 2019

Dari hasil penelitian ini, terjadinya fluktuasi permintaan yang menimbulkan kelebihan persediaan produk jadi pada permintaan rendah dan sebaliknya pada permintaan yang tinggi terjadinya kekurangan produk serta kurang optimalnya penggunaan kapasitas perusahaan, sehingga biaya perencanaan produksi menjadi tinggi. Permasalahan tersebut dapat ditanggapi dengan penelitian ini melalui perencanaan dan pengendalian produksi agregat yang dimulai dari proses peramalan permintaan, perencanaan agregat dengan strategi chase strategy dan level strategy.

Pada proses peramalan permintaan dapat diketahui perkiraan permintaan produk setiap bulan yang dapat mengurangi permasalahan kelebihan persediaan pada saat permintaan rendah dan kekurangan persediaan pada saat permintaan 
tinggi. Hasil dari peramalan permintaan ini dapat dijadikan sebagai dasar dalam proses selanjutnya yaitu membuat perencanaan agregat yang optimal.

Setelah diketahui perkiraan permintaan setiap bulannya kemudian dilakukan pembuatan perencanaan dan pengendalian produksi agregat. Proses ini merupakan proses penentuan jumlah, waktu produksi dan biaya produksi. Proses ini akan memberikan gambaran bagi perusahaan mengenai perkiraan jumlah produk yang harus diproduksi dalam satu tahun kedepan dengan menggunakan kapasitas perusahaan yang optimal sehingga dapat meminimalkan biaya produksi.

\section{SIMPULAN}

Berdasarkan hasil analisis data dan pembahasan yang telah dilakukan maka, dapat ditarik kesimpulan bahwa jumlah perkiraan produksi tedung untuk bulan Maret 2019 sampai bulan Februari sebanyak 31.531 unit/tahun, yang didasarkan pada hasil peramalan dengan metode exponential smoothing. Metode ini digunakan, karena metode exponential smoothing memberikan hasil yang memiliki standar error yang terkecil dengan nilai MAD sebesar 208.812, nilai MSE sebesar 61843.5 dan nilai MAPE sebesar $7.97 \%$. Perencanaan agregat yang memberikan biaya produksi terendah yaitu perencanaan agregat yang menggunakan chase strategy dengan total biaya sebesar Rp 242,995,500.00.

Berdasarkan kesimpulan pada penelitiaan ini, maka saran yang dapat diberikan yaitu UD Dwi Putri sebaiknya melakukan peramalan permintaan untuk mengatasi kelebihan produk jadi pada musim permintaan yang rendah atau sebaliknya kekurangan produk jadi pada musim permintaan yang tinggi dengan menggunakan metode exponential smoothing. Jumlah produksi yang sebaiknya dilakukan oleh UD Dwi Putri yaitu disesuaikan dengan permintaan karena dapat memberikan biaya produksi yang terendah.

\section{REFERENSI}

Amri, T., \& Harahap, E. N. (2012). Perencanaan Pengendalian Produksi Air Minum dalam Kemasan Menggunakan Metode Aggregate Planning. Malikussaleh Industrial Engineering Journal, 1(1), 11-18.

Carlos, G. da S., Figueira, J., Lisboa, J., \& Barman, S. (2006). Aninteractive Secisi on Support System for an Aggregate Production Planning Model Based on Multiple Criteria Mixed Integer Linier Programming. The International Journal of Management Science, 34(2), 167-177.

Cashiwan, \& Yudoko, G. (2016). Aggregate Planning Strategies at CV Saswco Perdana. Journal of Business and Management, 5(2), 267-276.

Cheraghalikhani, A., Khoshalhan, F., \& Mokhtari, H. (2019). Aggregate Production Planning: A Literature Review And Future Research Directions. International Journal of Industrial Engineering Computations, 10(1), 309330 . 
Fajar, M., \& Lestari, Y. D. (2017). Aggregate Planning Analysis in PT. Akebono Brake Astra Indonesia. Journal of Business and Management, 6(2), 182-191.

Gansterer, M. (2015). Aggregate Planning and Forecasting In Make-To-Order Production Systems. International Journal of Production Economics, 170(1), 521-528.

Gulsun, B., Tuzkaya, G., Tuzkaya, R., \& Onut, S. (2009). An Aggregate Production Planning Strategy Selection Methodology Based On Linear Physical Programming. International Journal of Industrial Engineering, 16(2), 135146.

Hairiyah, N., \& Amalia, R. R. (2018). Perencanaan Agregat Produksi Kelapa Parut Kering di PT. XYZ. Jurnal Teknologi Agro-Industri, 5(1), 32-41.

Haslindah, A., Sahi, S., \& Sartika, S. (2016). Perencanaan Agregat Untuk Memenuhi Permintaan Ikan Bandeng Tanpa Duri Pada Ikm 88 Marijo Di Kabupaten Pinrang. ILTEK, 11(22), 1607-1610.

Indra, H. (2017). Strategi Perencanaan Agregat Sebagai Pilihan Kapasitas Produksi. Jurnal Manajemen Bisnis Krisnadwipayana, 5(1), 2338-4798.

Jamalnia, A., Yang, J.-B., Xu, D.-L., Feili, A., \& Jamali, G. (2019). Evalution the Performance of Aggregate Production Planning Strategis under Uncertainty in Soft Drink Industry. Journal of Manufacturing Systems, 50(1), 146-162.

Jayakumar, A. A., Krishnaraj, C., \& Nachimuthu, A. . (2017). Aggregate Production Planning: Mixed Strategy. Journal of Biotechnology, 14(3), 487490.

Kalaf, B. A., Bakar, R. A., Soon, L. L., Monsi, M. Bin, Bakheet, A. J. K., \& Abbas, I. T. (2015). A Modified Fuzzy Multi-Objective Linear. International Journal of Pure and Applied Mathematics, 104(3), 339-352.

Li, B., Wang, H., Yang, J., Guo, M., \& Qi, C. (2013). A Beliefrule- Based Inference Method for Aggregate Production Planning Under Uncertainty. International Journal of Production Research, 5(1), 83-105.

Magrib, N. I. D. (2014). Perencanaan dan Pengendalian Produksi Untuk Peningkatan Mutu Produk Olahan Ikan. Jurnal Teknik Industri, 8(1), 19781105.

Martha, K. A., \& Setiawan, P. Y. (2018). Analisis Material Requitment Planning Produk Coconut Sugar pada Kul-Kul Fram. E-Journal Manajemen Unud, 7(12), 6532-6560. 
Mortezaei, N., Zulkifli, N., Hong, T. S., \& Yusuff, R. M. (2013). Multi-Objective Aggregate Production Planning Model with Fuzzy Parameters and Its Solving Methods. Life Science Journal, 10(4), 2406-2414.

Nisa, A. K., \& Kusuma, T. Y. T. (2017). Perencanaan Dan Pengendalian Produksi Dengan Metode Aggrate Planning Di C-Maxi Alloycast. Integrated Lab Journal, 5(2), 51-62.

Noegraheni, E., \& Nuradli, H. (2016). Aggregate Planning To Minimize Costof Production in Manufacturing Company. Binus Business Review, 7(1), 39-45.

Octavianti, I. A., Setyanto, N. W., \& Tantrika, C. F. M. (2013). Perencanaan Produksi Agregat Produk Tembakau Ranjang P01 dan P02 di PT X. Jurnal Rekayasa Perencanaan, 1(2), 264-274.

Rahmadhani, A., Rahma, A., Farela, C., \& Tantrika, M. (2014). Perencanaan Agregat Chase Strategy Dengan Analisis Kebutuhan Operator dan sesuai Fluktuasi Permintaan Rokok: Studi Kasus PR. Adi Bungsu, Malang. Jurnal Rekayasa Dan Manajemen Sistem Industri, 2(6), 1192-1201.

Sawargo, A. L., \& Mundari, S. (2014). Perencanaan Produksi untuk Memenuhi Permintaan Dengan Biaya Yang Optimal. Jurnal Teknik Industri, 11(2), 1693-8232.

Sultana, N., Shohan, S., \& Sufian, F. (2014). Aggregate Planning Using Transportation Method: A Casestudy in Cable Industry. Journal of Managing Value and Supply Chains, 5(3), 19-35.

Talapatra, S., Saha, M., \& Islam, M. A. (2015). Aggregate Planning Problem Solving Using Linear Programming Method. American Academic \& Scholarly Research Journal, 7(1), 20-28.

Yerandee., P., Predawut., S., Rungmanochai, P., \& Eamcharoenying, W. (2011). Integrated Aggregate Production and Marketing Promotion Planning under Uncertainty: A Case Study. The Asian International Journal of Science and Technology in Production and Manufacturing Engineering, 4(2), 15-27. 